\title{
Band keratopathy with bilateral deafness as a presenting sign of hyperparathyroidism
}

\author{
M. PETROHELOS, D. TRICOUlis, AND P. DiAmANTACOS \\ From the Department of Ophthalmology, Evangelismos Medical Centre, Athens
}

SUMMARY An unusual case of hyperparathyroidism is reported in which calcification of the cornea was the presenting clinical and diagnostic sign. Early recognition of this condition may be of lifesaving importance.

Calcification of the ocular tissues is fairly common and may occur either in cases of long-standing eye diseases or in systemic conditions causing alterations in the calcium and phosphate metabolism. In the majority of patients with hypercalcaemia the diagnosis has already been made, and the corneal and conjunctival deposits are found after careful examination by biomicroscopy. The purpose of this paper is to report a case of hyperparathyroidism in which the diagnosis was confirmed after the discovery of calcium deposits in the corneal and conjunctival tissues.

\section{Case report}

The patient was a housewife aged 24 who had been well up to about 18 months before admission to hospital. After a normal pregnancy and delivery she became nervous, irritable, and easily upset. About 8 months later she developed anorexia, nausea, vomiting, lost her appetite and lost weight, and suffered intermittent attacks of epigastric pain. A laparotomy was performed at that time and a diagnosis of acute pancreatitis was made. She was too weak to stand. Three months later she developed bilateral deafness, with marked decrease of vision and pronounced weakness and anorexia. She was placed on vitamin therapy, cortisone, and atropine eye drops. However, her condition steadily worsened until her admission to hospital. Her weight had dropped from a normal 130 to $69 \mathrm{lb}(59$ to $31 \mathrm{~kg})$.

On the day of her admission to hospital physical examination showed a chronically ill woman who was deaf bilaterally and had lost much weight. She wore a hearing aid without effect.

Address for reprints: Dr M. A. Petrohelos, 41 Academias, Athens 135, Greece
On physical examination the blood pressure was $135 / 85 \mathrm{mmHg}$. The thyroid was of normal size and no masses or nodes could be felt in the neck. The heart was of normal size. An apical systolic murmur could be heard. The finger nails showed bands of whitish discoloration and softness at the nail bases. Reflexes were very active throughout. Examination of the eyes on the day of admission revealed bilateral band-shaped corneal opacities, symmetrical in both eyes, which extended along the palpebral fissures without a definitely clear zone separating them from the periphery. The vision was $6 / 30-1$ OD and 6/9-2 OS. Examination with the slit lamp showed that the corneal opacities not only predominantly involved the palpebral fissures but extended to the lower portion of the cornea as well. A clear corneal zone of about $3 \mathrm{~mm}$ was present in the upper portion from 10 to 1 o'clock OU. The corneal changes consisted of a subepithelial diffuse collection of whitish material which was located in Bowman's membrane with direct focal illumination. The deep corneal layers were intact, and no vascularisation was present. The bulbar conjunctiva also showed glasslike subepithelial crystals temporally and nasally in the limbus. A diagnosis of band keratopathy, possibly due to hypercalcaemia, was made, and a biopsy of corneal and conjunctival tissues from the limbal area was done. The pathological report recorded a heavy deposit of crystalline material in the supporting tissue and beneath the epithelium. This substance took a pale blue stain with haemalum and eosin, indicating a probable calcium content.

Laboratory analysis showed the following serum values: serum calcium $16.2 \mathrm{mg} \quad(4.05 \mathrm{mmol} / \mathrm{l})$, inorganic phosphorus $4.1 \mathrm{mg}(1.3 \mathrm{mmol} / \mathrm{l})$, alkaline phosphatase 10.5 units, non-protein nitrogen $44 \mathrm{mg}$ $(31.4 \mathrm{mmol} / \mathrm{l})$, and total protein $6.0 \mathrm{~g} / 100 \mathrm{ml}(60 \mathrm{~g} / \mathrm{l})$ with an albumin-globulin ratio $2: 3$. The cerebro- 
spinal fluid calcium was $6.8 \mathrm{mg} / 100 \mathrm{ml}(1.7 \mathrm{mmol} / \mathrm{l})$.

Urine analysis showed a plus 1 reaction for albumin, 3 to 6 leucocytes, 0 to 3 red blood cells per $\mathrm{m}^{3}$ and exretion of 624 to $785 \mathrm{mg}(15.6$ to $19.8 \mathrm{mmol})$ of calcium in 24 hours. Examination in the otology department revealed the tympanic membranes to be covered with thick whitish plaques bilaterally resulting in a severe perceptive deafness. Roentgenograms showed decalcification of the long bones and the lamina dura. The upper gastrointestinal tract was negative and no calculi were observed in the gall bladder or the kidneys.

With a possible diagnosis of parathyroid adenoma an exploratory examination of the neck was done. It disclosed the presence of a large parathyroid tumour measuring $1.5 \times 1 \mathrm{~cm}$ in diameter, which was totally removed. Examination of the tumour showed it to be a parathyroid adenoma. The postoperative course was entirely uneventful. The patient's appetite increased remarkably, and with this she gained weight and a sense of well-being. A considerable improvement of the visual and auditory acuity was noticed. On the day of discharge the serum calcium was $10.7 \mathrm{mg} / 100 \mathrm{ml} \quad(2.7 \mathrm{mmol} / \mathrm{l})$ with inorganic phosphorus $4.3 \mathrm{mg} / 100 \mathrm{ml}(1.39 \mathrm{mmol} / \mathrm{l})$ and alkaline phosphatase 11.5 units.

She was re-examined a month later, and at that time her vision was $6 / 6 \mathrm{OU}$ and her hearing had returned to normal. Examination of the eyes with the slit lamp showed considerable reduction in the band keratopathy, with a practically clear pupillary area $\mathrm{OU}$ and only a residual opacity of about $2 \mathrm{~mm}$ in the limbal area temporally and nasally.

\section{Discussion}

The first reported observation on the deposition of calcium in the cornea and conjunctiva of patients with hyperparathyroidism is that of Walsh and Howard (1947).

Other workers supported this finding and reported a further series of patients (Cogan et al., 1948; Walsh and Murray, 1953; Berkow et al., 1968; Jensen, 1975). More recently Porter and Crombie (1973) described 4 patients in whom the diagnosis of hyperparathyroidism was confirmed after the discovery of calcium deposits in the cornea. Other systemic conditions producing calcification of the ocular tissues are well known, such as sarcoidosis, vitamin D intoxication, and chronic renal failure (Porter and Crombie, 1973). The ocular changes occur symmetrically in both eyes. In the conjunctiva the deposition of calcium variously described as white flecks or as glass-like crystals is primarily seen near the limbus running concentrically with the corneal margin. The corneal changes consist of a diffuse superficial milky opacity running as a band across the palpebral fissure.

The specific location of calcium in the cornea and conjunctiva differs in respect of the position in which it is deposited. Recent studies have shown that calcium salts are deposited intracellularly in patients with hyperparathyroidism, as opposed to the extracellular deposits in patients with renal failure and in band keratopathy without elevated blood calcium (Berkow et al., 1968; Jensen, 1975). From several points of view the reported case is most interesting. The presenting symptoms were loss of vision and hearing, and the corneal changes provided the first clinical evidence of hyperparathyroidism. The deposition of calcium in the tympanic membranes is rare, and to our knowledge has not been previously associated with this condition.

\section{References}

Berkow, J. W., Fine, B. S., and Zimmerman, L. E. (1968). Unusual ocular calcification in hyperparathyroidism. American Journal of Ophthalmology, 66, 812-824.

Cogan, D. G., Albright, F., and Bartter, F. C. (1948). Hypercalcemia and band keratopathy. Archives of Ophthalmology, 40, 624.

Jensen, O. A. (1975). Ocular calcifications in primary hyperparathyroidism. Acta Ophthalmologica, 53, 193-186.

Porter, R., and Crombie, A. L. (1973). Corneal and conjunctival calcification in chronic renal failure. British Journal of Ophthalmology, 57, 330-343.

Porter, R., and Crombie, A. L. (1973). Corneal calcification as a presenting and diagnostic sign in hyperparathyroidism. British Journal of Ophthalmology, 57, 665-668.

Walsh, F. B., and Howard, J. E. (1947). Conjunctival and corneal lesions in hypercalcemia. Journal of Clinical Endocrinology, 7, 644-652.

Walsh, F. B., and Murray, R. G. (1953). Ocular manifestations of disturbances in calcium metabolism. American Journal of Ophthalmology, 36, 1657. 